\title{
AFF4 wt Allele
}

National Cancer Institute

\section{Source}

National Cancer Institute. AFF4 wt Allele. NCI Thesaurus. Code C52504.

Human AFF4 wild-type allele is located in the vicinity of $5 \mathrm{q} 31$ and is approximately $88 \mathrm{~kb}$ in length. This allele, which encodes AF4/FMR2 family member 4 protein, is involved in transcriptional regulation. A chromosomal aberration involving this gene and the MLL gene, insertion ins(5;11)(q31;q13q23), is associated with acute lymphoblastic leukemia. 